\title{
DO WE HAVE REASONS TO OBEY THE LAW?
}

\author{
Edmund Tweedy Flanigan
}

$\prod$

N THIS PAPER, I shall ask whether we have content-independent moral reasons to obey the law, and I shall make some claims about what we mean when we ask this question. I shall also inquire after the strength of such reasons. In other words, I shall ask whether we ought morally to do as the law demands, because the law demands it.

This is a version of a very old question, but it is in one important way different from that question. Traditionally, we ask whether subjects are morally obligated to obey the law, or whether, equivalently, they have a moral duty to do so. ${ }^{1} \mathrm{I}$ believe we should instead begin with the more modest question of whether we have moral reasons to obey the law. This question retains the structure of the traditional question, but it is at the same time simpler and clearer, and so easier to answer. Moreover, many take reasons to contribute to obligations, so in answering the question about reasons, we may also make progress on the question about obligation. ${ }^{2}$

The answer to this question I shall defend is yes: we do very often have moral reasons to obey the law, because it is the law, in the content-independent sense. Moreover, I shall suggest that these reasons very often amount to an obligation to so act.

This answer goes against a strong current in political and legal philosophy which has led many to endorse philosophical anarchism, the family of views often expressed by some combination of the claims $1-3:{ }^{3}$

1 Following common practice in this literature, I will not distinguish between obligation and duty. My discussion of the former should be read as applying as well to the latter. The bestknown view that does distinguish between these concepts in this context is Rawls's. For him, obligations are interpersonally incurred (like promises, for example), whereas duties may be "natural." See Rawls, A Theory of Justice, 98-101, sec. 19.

2 I substantiate this point in slightly greater detail in the next section. Beyond this, the benefit of asking the reasons question before the obligation question will also (I hope) be demonstrated by the fruit of what follows, taken as a whole.

3 Matthew Noah Smith goes so far as to write that "there may be a consensus amongst moral and political philosophers that there is not today any existing obligation to obey the law" 
1. Any reasons we may seem to have to do as the law demands are really just reasons to do as we ought full stop, independent of the law, in virtue of our ordinary moral obligations; or

2. Whatever conditions would obligate us to do as the law demands are not met, and maybe could not be met, by the law; or

3. Any such apparent reasons are merely prudential reasons to act so as to avoid being fined or punished by the state.

The law, on any of these views, is not morally significant. ${ }^{4}$

Separately, some have been recently convinced that there can be no content-independent reasons to obey the law, or at least that no successful account of what such reasons might amount to has yet been given. ${ }^{5}$ This separate conclusion only strengthens the appeal of the philosophical anarchist's claim, by undermining the very possibility of having a reason to do as the law demands because it is what the law demands.

I believe we can answer both of these skeptical challenges. Content independence is not as mysterious as it has often been made to seem. On the view I propose, when we talk of content independence, we are making claims about grounding. When we claim that the law provides content-independent reasons for its subjects to $\phi$, we are claiming that there is a distinctive property of the law which grounds a moral reason to $\phi$, which is another way of claiming simply that the law's distinctive properties are morally significant.

When we understand content independence in this way, it becomes easier to see that the law very plausibly does provide content-independent reasons to do as it demands. We can also see that such reasons may often combine, sometimes with nonlegal reasons and sometimes on their own, to amount to an obligation to obey the law. While my remarks on this point must remain schematic_-whether we are in fact obligated by the law depends on further commitments regarding the status and normative force of various candidate properties of the law, regarding the normative circumstances of particular subjects, as well as regarding com-

("Political Obligation and the Self"). Similar claims may be found in Edmundson, "State of the Art”; Gur, "Are Legal Rules Content-Independent Reasons?”; Klosko, "Are Political Obligations Content Independent?"

4 I do not here address Wolff's early anarchist view, which focuses on the agential costs to following an authority's directive, nor Smith's recent defense of a related view. To address these views, distinctive as they are, would require a separate paper. As Smith notes, moreover, that view "has never had much traction" in the literature (though his paper is an attempt to revive it). See Wolff, In Defense of Anarchism; Smith, "Political Obligation and the Self."

5 See Markwick, "Law and Content-Independent Reasons" and "Independent of Content." Sciaraffa argues for a similar conclusion ("On Content-Independent Reasons"). 
peting conceptions of the concept of obligation-we can nevertheless conclude that, very plausibly, the law often succeeds in morally obligating us. The anarchist's position is thus importantly undermined.

\section{PRELIMINARIES}

It may help to begin by first offering some definitions and clarifications, if only because the literature on political obligation has suffered, in my view, from some unclarity about reasons. I follow Scanlon and Parfit in using the "purely" or "genuinely" normative concept of a reason, according to which a reason to $\phi$ may be helpfully redescribed as a fact that counts in favor of $\phi$-ing. ${ }^{6}$ To have at least one reason to $\phi$ is the same as having "some reason," or simply "reasons" to $\phi$, though we may have some reason to $\phi$ even when there is some other act that we ought to do instead, because the reasons favoring that act are stronger than our reasons to $\phi .{ }^{7}$ When the balance of reasons counts decisively in favor of our $\phi$-ing, in the sense that our reasons to $\phi$ outweigh any competing reasons not to $\phi$, or to do some other act instead, we can say that we have "decisive reason" to $\phi$, which is one way of saying simply that we ought to $\phi .{ }^{8}$ If our reasons are such that we may permissibly $\phi$ but are not required to $\phi$, we say that we have "sufficient reason" to $\phi$.

When I speak of someone's "having" a reason to $\phi$, I do not mean to imply anything about this person's own awareness of her reasons, nor about her motivational states. ${ }^{9}$ In the way I use the term, a person's having a reason to $\phi$ is just the same as there being a reason for her to $\phi$, which is just the same as there being some fact that counts in favor of her $\phi$-ing. Similarly, when I say that some fact "gives" or "provides" us with a reason to $\phi$, I mean only that that fact is a reason for us to $\phi$, by counting in favor of our $\phi$-ing. By extension, when I say that the law gives or provides us with a reason to $\phi$, I mean that the fact that the law demands that we $\phi$ is a reason for us to $\phi$, or counts in favor of our $\phi$-ing. ${ }^{10} \mathrm{In}$

6 Scanlon, Being Realistic about Reasons, 1-15; Parfit, On What Matters, 1:31-37.

7 Some refer to these as pro tanto reasons, as a way of indicating that these reasons can weigh together, outweigh, and be outweighed by other reasons. For my purposes, writing "pro tanto" in front of "reason" does not add anything, as all of the reasons I discuss can weigh together, outweigh, and can be outweighed by other reasons.

8 There are other senses of "ought," but I shall stick to the decisive reason-implying sense here.

9 The exception to this is when I consider the view, defended by Hart and Raz, that our reasons to obey the law require that we act for certain reasons and not others. See section 3.2 below.

10 It may be natural to talk of some people, or even the law, "giving reasons" to others, but such talk is often misleading, and I shall avoid it. Facts supply reasons, and the only helpful 
this paper I shall discuss only ideal cases, so there will be no need to distinguish between reasons for action and the merely apparent or contextually normative reasons for action that we may be said to have, or be aware of, in virtue of our beliefs about which facts count in favor of which acts. Only in these nonideal cases is it useful, I believe, to talk of someone's "having a reason" in this other sense, and similarly, only in nonideal cases is it useful to talk of something "giving" a reason to someone in the corresponding sense.

Additionally, it is important to say that I take myself to be discussing moral reasons, as distinct from merely prudential reasons, epistemic reasons, reasons of rationality, and so on. I do not take a view on the issue of what makes our moral reasons distinct from other kinds of normative reasons; I claim only that there is a useful distinction to be drawn.

Another point of unclarity in the literature has been regarding the nature of obligation. As mentioned already, we are traditionally confronted with what I shall call the "obligation question," which asks,

Are subjects obligated to do as the law demands, in virtue of it so demanding?

However, rather than begin with the obligation question, I suggest that we first ask the more modest "reasons question":

Do subjects have reasons to do as the law demands, because the law demands it?

This is for several reasons. First, because the concept of obligation, particularly in this context, is insufficiently clear. Its various conceptions are not normally well distinguished, yet what we mean by " $S$ is obligated to $\phi$ " of course bears importantly on what we should think about whether subjects are obligated to obey the law. ${ }^{11}$ Second, the concept of a reason is simpler, as well as (arguably) more

sense in which people may give reasons to others is by helping create (as by promising or commanding) or by calling attention to (as by pointing out) such facts. On this point, see Enoch, "Reason-Giving and the Law."

11 For instance, a common thought is that for $S$ to be under a moral obligation to $\phi$ is for it to be wrong for $S$ not to $\phi$. While this may be an attractive understanding of moral obligation in general, it is less clearly helpful in the context at hand, not least because it is unclear who or what would be wronged by a failure to obey the law. By contrast, Green analyzes obligations in this context as requirements with which subjects are "bound to conform," where the notion of being bound is explained as being "nonoptional" or compulsory. See Green, "Legal Obligation and Authority" (emphasis in original). He is here following Hart, who makes similar remarks in "Legal and Moral Obligation." This is intuitively closer to what I believe most theorists in this literature have in mind, although it is clearly stronger than the 
fundamental, than the concept of an obligation. We can thus more clearly know what we are asking when we ask the reasons question, and so we can more clearly know whether we have an answer. Third, and relatedly, because it is widely thought (and I believe) that reasons contribute to obligations. Precisely how they do so is a matter of debate, though we need not make any more specific commitments here than that they $d o$. If it is true that reasons contribute to obligations, then in answering the reasons question, we have also (at least partly) answered the obligation question.

Because I ultimately wish to discuss philosophical anarchism, whose standard formulation denies that subjects are morally obligated to obey the law, I will not be able to entirely avoid obligation talk. For our purposes, I shall use "normally decisive reason" as a moderately ecumenical analysis of the concept of obligation. This is not because I take it to be a particularly good analysis of what obligation is (it is not), but rather because it seems extensionally compatible with many reasonable ways of speaking about obligation and duty, such as when Ross discusses our "prima facie duties" to act in certain ways, and also with the idea that obligations are those acts which are, in view of the balance of reasons, morally required. ${ }^{12}$ Still, my use is a substantive commitment, and so alternative conceptions of obligation may lead to disagreement with my claims later in the paper about our reasons to reject philosophical anarchism. Since I know of no anarchist position that understands obligation in a way that is incompatible with my commitment here, it would fall to the anarchist to develop such a position.

Finally, it should be borne in mind throughout that we must always be careful to distinguish some reason for action $[r]$ from a "summary reason" given by a set of reasons for that action that includes $[r]$ as one member among others of the set, lest we double count the reasons. ${ }^{13}$ Thus, to borrow Parfit's example, the fact that some medicine is the cheapest and most effective may make it the best medicine, but when we talk of the reasons for some person to take this medicine, we would make a mistake if we claim that this person has three reasons to do so: that it is the cheapest, the most effective, and the best.

previous conception. Moreover, these further notions (of being "bound," "nonoptionality," and so on) are hardly more perspicuous than the original.

Edmundson makes a similar claim, writing that the duty to obey the law is regarded "as one that is ordinarily decisive" despite being "subject to being defeated or outweighed by countervailing moral considerations." See "State of the Art," 215-16.

Throughout the paper, I will use brackets to indicate facts: " $[r]$ " means "the fact that $r$." 


\section{CONTENT INDEPENDENCE}

We can now consider the idea of the content independence of certain reasons, including reasons given by the law. Roughly, the idea is that a reason is content independent if, as Hart puts it, it is "intended to function as a reason independently of the nature or character of the actions to be done"; or, as Raz puts it, if "there is no direct connection between the reason and the action for which it is a reason."14 In the case of content-independent "legal reasons" - the reasons given by acts being prohibited, permitted, or required by the law-we say that such reasons are to do as the law demands, whatever the law demands, no matter the moral, rational, or perhaps even legal merits of what is demanded. ${ }^{15}$ Taken another way, the idea of content independence is the thing that we mean by "because it is the law" when we discuss the claim that we have reasons to obey the law because it is the law.

It will help to begin by discussing a recent skeptical challenge. The legal philosopher Paul Markwick has rightly questioned the idea that all reasons are, as such, either content dependent or content independent. Reasons are, I have claimed, facts that count in favor of actions. On this understanding, it is mysterious what it would mean to claim that some reasons bear the fundamental property of content dependence while others bear the fundamental property of content independence. What is the content of a reason, other than the fact that constitutes it, or that fact's propositional content? How could any reason be independent of that? And what would we add to the claim that $[r]$ is a reason for someone to $\phi$ by making the further claim that that reason is dependent upon or independent of $r$ ? It is not clear that such a claim would even make sense.

Most of those who claim content independence for legal reasons do not take the content in question to be the content of the reason per se but rather the thing that the reason is a reason to do. Thus, for some reason to $\phi$, the content of that reason is $\phi$, or $\phi$-ing. ${ }^{16}$ It is this that Markwick has in mind when he argues that legal reasons are not distinctively content independent. As I shall now argue, I think Markwick is correct in this view but also partly misled by his argument, so

14 Hart, Essays on Bentham, 254; Raz, The Morality of Freedom, 35-37. It has often been remarked, pace Hart, that intention seems largely beside the point.

15 The notion is typically understood to allow limiting cases, such as when the law's demands are grossly immoral or unjust, or perhaps when the law's demands are too demanding. I shall ignore such limiting cases-while acknowledging their deep importance in other contexts-for the purposes of this discussion.

16 Strictly speaking, it thus seems both more accurate and clearer to refer to $\phi$ as the object of $S$ 's reason to $\phi$ rather than its content, but it is probably too late to correct that particular error. 
that he rejects the notion of the content independence of legal reasons altogether as uninteresting or uninformative. I do think legal reasons are not distinctively content independent, but I do not think the notion is therefore uninteresting or uninformative. Rather, I think that by better understanding the sense in which legal reasons are often claimed to be content independent, and by seeing how such reasons are not so unlike other kinds of normative reasons, we can better see how we might have reasons to obey the law because it is the law.

In one paper, Markwick considers the following candidate condition for content independence of reasons:

If $\phi$-ing's $F$-ness is a reason to $\phi$, this reason is content independent if and only if for any other act-type $\mu$, there would be a reason to $\mu$ if $F$ were a property of $\mu$-ing. ${ }^{17}$

We can restate this condition briefly as the claim that a reason to act is content independent just in case the reason is given by some property of the act such that, if another act had that property, it would also provide a reason to so act.

This seems, at first glance, like a good account of content independence. If some act has the property of being required by the law, for instance, and if having this property provides a reason to so act, then there will be a like reason to do any other act that also has the property of being required by the law. The reason given by the fact that an act is required by the law, then, would appear to be a content-independent reason.

Markwick points out, however, that this condition seems to capture too many reason types. Many acts are morally required, for example, and thus share the property of being required by morality. The reasons given by the fact that these acts are morally required thereby meet the condition above for content independence. And yet moral reasons are not typically taken to be content independent. They are, rather, commonly taken to be content dependent. We can also ask, if moral reasons are content independent, then which reasons are content dependent? The same point could be made about several other properties typically not thought to confer content independence upon the reasons they provide. Markwick gives two examples: the property of causing unnecessary suffering and the property of maximizing utility. Take the property of causing unnecessary suffering. That an act bears this property is a reason not to do it and would be a reason

17 Markwick, "Law and Content-Independent Reasons," 582. In this paper and in "Independent of Content," Markwick often uses the phrase "a reason" to $\phi$ to mean sufficient or decisive reason to $\phi$. As I shall argue, however, it is much easier to argue that the law does not in all cases provide, on its own, sufficient reason to do as it demands, than to argue that it does not provide a reason, or any reasons, to so act. We should consider the latter claim about reasons first, and only then move on to stronger claims about sufficient and decisive reasons. 
not to do any other act bearing this property. Such a reason would thus meet the condition above for content independence. Yet such a reason, as Markwick notes, is commonly taken to be a clear example of a content-dependent reason. Or take the property of maximizing utility. According to act utilitarianism, an act is required if and only if it maximizes utility, no matter any other features of the act (e.g., that doing it would break some promise, violate some people's rights, etc.). In other words, we might say, all and only utility-maximizing acts are required, regardless of their content. Yet surely, Markwick claims, no act utilitarian would claim that all such acts are required by content-independent reasons. For again, the question could be asked, if these reasons are content independent, then which reasons are content dependent? The objection, in brief, is that the fact that it is unclear which reasons might be content dependent casts doubt upon the viability and usefulness of the distinction between content dependence and independence, and further that it is "unclear how content independence is a property which distinguishes legal reasons in particular from reasons in general." ${ }^{18}$ If no reasons, or few reasons, are content dependent, or if we cannot use the property to distinguish legal reasons from reasons in general, we might urge along with Markwick that we give up on talk of content independence as an important feature of legal reasons altogether, as uninteresting or uninformative.

Part of the answer to Markwick's challenge is to concede that content independence is not a distinctive property of legal reasons but to maintain that, when we claim of some reasons, including legal reasons, that they are content independent, we are making a claim that is nevertheless both interesting and informative. This is because to claim that

some property of an act gives us a reason to do that act, and gives this reason the property of being content independent

is, in my view, to claim nothing more than that

this property of the act is normative, in the sense that an act's having it gives us a reason to do that act regardless of any other facts about the act.

It is interesting and informative to claim of some reasons that they are content independent simply because it is interesting and informative to claim of some properties of acts that they are normative, in the sense that they give us reasons to do those acts. It is both interesting, and would be highly informative if true, to claim that an act's maximizing utility gives us a reason to do that act, as the act utilitarian's main thesis claims. If we could truly make a similar claim of many other properties, this too would be highly informative and interesting. Such

Markwick, "Law and Content-Independent Reasons," 592. 
properties include the property of being loved by the gods, the property of being required by the king, the property of being an act whose maxim everyone could will to be a universal law of nature, and many others, including the property of being demanded by the law. It would be informative and interesting if the property of being demanded by the law were normative, in the sense that an act's having this property provided a reason to do that act whatever this act may $b e$. This is why, even conceding that content independence is not a distinctive feature of legal reasons, we may nevertheless claim that it would be interesting and informative if some legal reasons bore that property. ${ }^{19}$

It may seem, I should acknowledge now, that I have already conceded too much. If content independence is not a distinctive property of legal reasons, or if it is just another way of making the obvious claim that some reasons are given by normative properties of acts, then it may be hard to believe that I am indeed making a claim that is interesting or informative. But an important part of my thesis is that legal reasons are not as unlike other normative reasons as is commonly believed, and that when we claim that legal reasons are content independent, we are (at least) tacitly committing ourselves to this conclusion. Furthermore, I believe that understanding this can help to make sense of the ways in which the law may in fact be a source of genuinely normative reasons for action, such that we may truly claim that we have reasons to obey the law because it is the law.

An anonymous reviewer points out that Markwick's challenge might be thought to be directed at a straw man, in light of Rawls's famous distinction between the justification of a practice, following the rule-utilitarian maxim, and the justification of an act falling under a practice, following the act-utilitarian maxim. See Rawls, “Two Concepts of Rules.” On Rawls's view, legal reasons pertain principally to the justification of practices and should therefore be construed as rule utilitarian in nature, rendering Markwick's act-utilitarian examples inapt. I take the point to be friendly: if the answer to the question (say) "ought I to obey my promise to $\phi$ ?" should be given in terms of my reasons to obey my promises rather than my reasons to $\phi$, then there is a clear element of content independence to those reasons. If my legal reasons are generally of this nature, then the same will be true of them. That this characteristic may be shared by legal reasons and other rule-utilitarian reasons-and especially if we think the character of morality in general is rule utilitarian (or rule consequentialist) in nature-would not, on my view, show the property of content independence to be uninteresting or uninformative with respect to our reasons to obey the law.

The same reviewer notes that on Rawls's view, asking about the justification of a practice introduces an important opacity regarding the justification of acts falling under that practice, at least when those acts are constituted by the practice. The thought is that (for instance) if I have promised to $\phi$, the fact that I ought to obey my promises renders inappropriate further inquiry regarding the question of whether I ought to $\phi$. I take the view I propose to be compatible with various thoughts about "opaque" or "excluded" reasons, a point I discuss extensively in section 3.2 below. 
To see how this is so, it will help now to more fully explain my view of content independence. On my view, we should understand claims of content independence as grounding claims. ${ }^{20}$ When we claim that some fact $[p]$ grounds another fact $[q]$, we can equivalently claim that

$[p]$ makes $[q]$ true, or makes it the case that $q$;

$[q]$ is true, or holds, in virtue of $[p]$;

$[q]$ depends on $[p]$;

$[q]$ holds because of $[p]$.

The grounding relation is not, it is worth emphasizing, a causal relation, nor the supervenience relation, nor is it the same as specifying the necessary conditions for some fact to hold - though instances of these other relations may sometimes coincide with instances of the grounding relation. It is, rather, the relation of one fact's making the case another fact and thereby noncausally explaining that fact. It is, appropriately to the current discussion, a dependency relation.

The relation, though difficult to define, is very familiar in normative theorizing. Consider these examples:

1. Locke writes that "this original Law of Nature for the beginning of Property, in what was before common, still takes place; and by vertue thereof, what Fish any one catches in the Ocean, that great and still remaining Common of Mankind ... is by the Labour that removes it out of that common state Nature left it in, made his Property who takes that pains about it." ${ }^{21}$

2. Ross asks "What makes acts right?" and answers that "the ground of the actual rightness of [an] act is that, of all acts possible for the agent in the circumstances, it is that whose prima facie rightness in the respects in which it is prima facie right most outweighs its prima facie wrongness in any respects in which it is prima facie wrong."22

3. Rawls writes that the principles generated in the original position "must hold for everyone in virtue of their being moral persons" and that the basis of equality lies in "the features of human beings in virtue of which they are to be treated in accordance with the principles of justice." 23

See inter alia Berker, "The Unity of Grounding"; Fine, "Guide to Ground”; Rosen, "Metaphysical Dependence."

21 Locke, Two Treatises of Government, ch. 5, sec. 29 (emphasis added).

22 Ross, The Right and the Good, 46 (emphasis added on "makes").

23 Rawls, A Theory of Justice, 114, 441 (emphasis added). 
4. Cohen discusses the "Pareto claim" that "inequality is indeed just when and because it has the particular consequence that it causes everyone to be better off." 24

5. Some people claim that a person deserves some treatment because of this person's prior acts or bad character.

The grounding relation is normatively indispensable; there are very many other such examples all around us. ${ }^{25}$

The claim that legal reasons are content independent is a claim about which features of the law can make it the case that we have reasons to do as it demands. When we consider the claim that we ought to obey the law because it is the law, the "because" is the because of grounding. When we consider the claim that it is in virtue of being against the law that some act is wrong, rather than due to the "merits of the act itself," we are considering the claim that some feature of the law that is not also a feature of the act demanded by the law is what makes the act wrongful, or what grounds its wrongness.

Put most simply, the claim is that

[The law demands that $S \phi]$ grounds [ $S$ has a reason to $\phi]$.

However, to claim just that [The law demands that $S \phi$ ] grounds [ $S$ has a reason to $\phi$ ] may be misleading, for demands do not by themselves ground reasons for action. Rather, it is only in combination with the facts that legitimate those demands that they may do this. If the law's demands can ground reasons for action, there must be some further feature of the law that gives its demands this force.

In many cases, it is worth noting, a legitimate demand may play no part at all in grounding a reason for action. This may be easiest to see by considering a basic case of promising. Suppose I have made you a promise that I will $\phi$, and that you subsequently demand that I fulfill my promise. We could not then claim that

[You demand that I fulfill my promise to $\phi$ ] grounds [I have a reason to $\phi$ ]

because it is not your demand but my promise which grounds the obligation: I

of just how often the normative grounding relation is appealed to. Nor is this a distinctively contemporary or even modern phenomenon. When Plato's Euthyphro asks whether acts are pious because the gods love them, or loved by the gods because they are pious, he is asking a question about normative grounding. (In "No Church in the Wild," Jay-Z asks the same question poetically: “Is Pious pious 'cause God loves pious?” He too is asking a question about grounding.) 
would have a reason to fulfill my promise regardless of whether you demanded that I do so or not. More fully, it is in virtue of my having made a promise to you both that you may make a genuinely normative demand of me that I fulfill my promise and that I have a reason to do so.

By contrast, some demands may seem to by themselves ground reasons for action. Certain demands by those we love, for example, or to whom we otherwise have special obligations, may seem to be clear cases of this kind. If your child demands love and attention, for instance, it may seem that

[Your child demands love and attention] grounds [You have a reason to give your child love and attention].

But even in this case, it would be better to claim that your child's demand together with your special obligations to your child ground your reason for action. To claim only that your child's demand grounds your reason for action would be misleading, and to claim that your child's demand by itself grounds your reason for action would be false.

Similar remarks apply to the law's demands on us. In order to make plausible the claim that the law's demands ground reasons for action, we need to identify some property or properties of the law in virtue of which its demands are genuinely normative. In other words, it is only in virtue of some normative property or properties of the law together with the fact that the law makes specific demands of us that we may come to have reasons to do as it demands. We should therefore consider the revised claim that

[The law has some properties $\{P\}]$ and [The law demands that $S \phi]$ together ground $[S$ has a reason to $\phi]$.

Note that we are now discussing the possibility of several facts together grounding a single fact. To understand this, it may help to make explicit my assumption that not all grounding relations between one fact and another are relations of full grounding; many are relations of partial grounding. One fact $[p]$ partially grounds another $[q]$ when $[p]$ helps make $[q]$ true, or helps make it the case that $[q]$, or when $[q]$ holds partly in virtue of, or partly because of, $[p]$. The fact that $S$ has a reason to $\phi$, for example, would partially ground the fact that $S$ ought to $\phi$, by contributing to the set of reasons for $S$ to $\phi$. The set of reasons such that $S$ has more reason to $\phi$ than to do any alternative act fully grounds the fact that $S$ has decisive reason to $\phi$, by fully making it the case that $S$ ought to $\phi .{ }^{26}$ The claim I wish to make may indeed be more fully stated as the claim that

There are also many nonnormative examples of the distinction between full and partial 
Each of the facts [The law has some properties $\{P\}]$ and [The law demands that $S \phi$ ] partially ground, and together fully ground, [ $S$ has a reason to $\phi]^{27}$

This claim about the content independence of legal reasons can be made in other, equivalent ways. The grounding claim made by claims of content independence of the law is also a claim about what does not fully ground a person's reason for action. Namely, it is the claim that the fact that a law demands that $S \phi$, and indeed all facts about $\phi$-ing, do not fully ground the reason given by the law for $S$ to $\phi$. Or in other words, the legal reason for $S$ to $\phi$ is independent of facts about $\phi$-ing, where "independent" is to be understood as a negative grounding claim. The positive grounding claim is that when $S$ has a content-independent reason to obey the law's demand that $S \phi$, this reason is at least partially grounded by some fact or facts about the law that are not also facts about $\phi$-ing. These facts are about the normative properties of the law in general, as distinct from any particular action the law requires or forbids.

Understanding the claim that legal reasons provide content-independent reasons for action as a claim about grounding helps make sense of a number of cases in which, intuitively, it may be unclear whether the law provides a genuinely normative, content-independent moral reason to do as it demands. Imagine, for instance, a society in which the law is merely a codification of morality, such as that of the Israelite tribe under Moses: Moses's tablets, we can imagine, were a codification of the independently normative moral truths given to the Israelites by God. We might then imagine one Israelite appealing to another, more murderously inclined Israelite that the tablets forbid killing. "You must not kill, because it is against the law," the one might say. What should we make of the first Israelite's appeal to the second?

Let us grant that the second Israelite in fact has a reason not to kill. If the first Israelite's appeal is meant to make a claim about what grounds the second Israelite's reason, then that claim is false, since the fact that "THOU SHALT NOT

grounding, which may be clearer: [The apple is golden and delicious] is fully grounded by [The apple is golden] and [The apple is delicious] together, and partially grounded by each of those facts separately.

27 One of the law's properties is of course that it demands that $S \phi$, and another is, presumably, that it demands that a certain set of people including but not solely consisting of $S \phi$. The first would merely repeat [The law demands that $S \phi$ ], since to make this claim is to make the claim that the law has the property of demanding that $S \phi$, so would not in that case constitute additional partial grounding for [S has a reason to $\phi]$. As for the second, to claim that the wider [The law demands that a set of people $\{S, \ldots\} \phi]$ together with its instantiation [The law demands that $S \phi$ ] grounds (if indeed it does ground) [ $S$ has a reason to $\phi$ ] is not importantly different from simply claiming that the instantiation alone can do this work. 
KILL" is written on Moses's tablets certainly does not ground the second Israelite's reason not to kill-it is rather the moral prohibition on killing, given to the Israelites by God and recorded by Moses on the tablets, that does this. Just as the wind's happening to spell out "THOU SHALT NOT KILL" in the sand would not itself be a reason not to kill, etchings of God's moral law in stone would not themselves provide reasons for action. Only speaking loosely may we claim that an act's being prohibited by Moses's tablets is a reason for the Israelites not to do it, and when we make such a claim, it must be either false or else, more charitably, be a shorthand way of making the more accurate claim that the act is prohibited by God. This is because, in the case we are imagining, God's prohibition is genuinely normative, whereas being codified on Moses's tablets, or being written by the wind in the sand, is not.

More generally, when demanding that for each morally required act, $S$ do that act, we would make a mistake by claiming that

[The law codifies morality] and [The law demands that $S \phi$ ] together ground $[S$ has a reason to $\phi]$.

For it would be in virtue of $\phi$-ing's being morally required, rather than in virtue of the law's demanding or codifying that $S \phi$, that $S$ has a reason to $\phi$. These further facts about the law would add nothing to the normative grounds for $S$ 's $\phi$-ing, which is to say would not help to make it the case that $S$ has a reason to $\phi$. In the same way, if I told you truly that you ought morally to do some act, and even if I always told you truly what the thing was you ought to do, it would be in virtue of this act's being a moral requirement, rather than in virtue of my telling you so, that you ought to do it. In this way, the law cannot be said to provide content-independent reasons for action in cases in which it is merely a codification of more fundamental normative facts.

Similarly, we can, by understanding content independence as an idea about normative grounding, better understand the sense in which Markwick rightly claims that legal reasons are not distinctively content independent. The claim that legal reasons are content independent is no more than the claim that some legal property of these reasons, such as (say) that it was passed by a democratic assembly, or that it solves some coordination problem - rather than something about what it is these legal reasons are reasons to do-is what makes it the case that they are genuinely normative for those to whom they apply; just as, according to one widely held view, moral reasons are made genuinely normative not by facts about what they are reasons to do but by facts about morality, such as that the act for which the reason counts in favor would maximize utility, or is an act that no one could reasonably reject, or is an act that is in conformity with a 
maxim that could be willed to be a universal law, and so on. But we can also in this way understand why the further worry that, by failing to be distinctive, the content independence of legal reasons may be uninformative or uninteresting, is misplaced. For the claim that legal reasons are content independent is the important and substantive claim that the law, like morality, can be a source of genuinely normative moral reasons for action, rather than merely a way of calling attention to reasons whose real normative force lies elsewhere.

\section{OBJECTIONS}

It is worth pausing now to consider some objections against the view I have proposed. First, I will consider several versions of the objection that the view fails on its own terms, since all moral reasons are ultimately grounded in facts about morality rather than the law. By explaining how this objection fails, the distinctive character of the grounding view of content independence will become clearer. Second, I will address the objection that by analyzing content independence in terms of the grounds of reasons to obey the law, I have lost (or worse, am unable to accommodate) a distinctive and important feature of our reasons to obey the law, namely, the opacity of such reasons to those subject to them. In considering these objections, I will compare my view with well-known views represented by Hart, Raz, and Rawls.

\subsection{Internal Objections}

To begin, it may be objected that any moral force the law has must be had in virtue of some prior moral facts, and that in view of this, no obligation to do as the law demands may be said to hold in virtue of facts about the law. This objection may take two forms. On the first, the complaint is that the law is, like Moses's tablets, a mere codification of some other normative facts, and that thus we may not properly claim that it is the law which grounds our reasons to do as it demands.

To answer this first version of the objection, it is important to understand the sense in which one fact's grounding another provides a noncausal explanation for the second fact. [The apple is golden] and [The apple is delicious] together ground and thereby explain [The apple is golden and delicious]. Similarly, according to act utilitarians, the claim that [The act would maximize utility] grounds and thereby explains [The act is required]. By contrast, if we imagine some person who always speaks truly, [This person says that the apple is golden and delicious] would not ground [The apple is golden and delicious], because this person's claim, though true, would not explain [This apple is golden and 
delicious]. Nor would, for the act utilitarian, [This person says that the act is required] ground or explain [The act is required]. To explain in this noncausal way seems to be part of what it is to ground.

Now compare two similar cases. In the first, suppose that some king's dictates are independently normatively binding on his subjects, and suppose further that those dictates are published in a book of codes. In one sense, we could plausibly claim that [This act is prohibited by the codebook] grounds [This act must not be done], but only insofar as [This act is prohibited by the codebook] refers not to the physical book but to the abstract collection of dictates recorded there, so that [This act is prohibited by the codebook] is a shorthand for [This act is prohibited by the king's dictates]. This is like the way in which we can only truly claim that an act's being prohibited by Moses's tablets grounds our reasons not to do this act if we more fully mean that it is God's prohibition, which the tablets record, that grounds our reason not to do this act. In this way, there is an important sense in which we may properly say that an act's being prohibited by the codebook noncausally explains the fact that we must not do this act.

In the second case, suppose that some unofficial observer privately records the king's dictates in a notebook. In contrast with the first case, we could not then plausibly claim that [This act is prohibited by the notebook] grounds [This act must not be done], because the notebook is a mere private record of the king's dictates, and [This act is prohibited by the notebook] could not plausibly be a shorthand for the claim that the act is prohibited by the king. It is more like the wind writing "THOU SHALT NOT KILL" in the sand, or like, when I truly tell you that you ought not to do some act, it is not my telling you so that explains the fact that you ought not to do it. There is no sense in which being prohibited by the notebook noncausally explains the fact that some act must not be done.

When we claim that

[The law has some properties $\{P\}]$ and [The law demands that $S \phi$ ] together ground $[S$ has a reason to $\phi]$,

we are, as in the first case, making a noncausal explanatory claim. There will be further facts which ground the fact that the law has such properties, as well as, more pertinently, further facts about what makes those properties give the law normative force. If there are such properties of the law, however, which together with its demands ground reasons for us to obey it, we may properly say that those facts ground reasons for action, and we may properly refer to such reasons as reasons to obey the law because it is the law.

A second version of this objection argues that, when we claim that some properties of the law help ground a reason for us to do as it demands, we ought 
instead to claim that it is those properties, or whatever grounds them, that ground our reasons to do as the law demands, rather than the law itself. If some facts about the democratic origins of a law, for instance, are what make it the case that we have a reason to do as it demands, then, according to this objection, we should say that it is those origins, rather than the law itself, which give us such a reason. We should, on this objection, follow the normative grounding "all the way back," and then make any grounding claims in terms of those fundamental normative grounds.

One answer to this objection is to agree that we may often be able to make grounding claims in terms of other, more fundamental grounds by following the chain of grounding "back," but to deny that such a move is always better. Indeed, it may on many occasions be worse to do this. When claiming that

[The apple is golden] and [The apple is delicious] together ground [The apple is golden and delicious]

it may not help, or it may be unnecessary, to reformulate the claim in terms of the very many further facts which ground [The apple is golden] and [The apple is delicious] separately. The same may be said of the facts that ground our reasons to obey the law.

Another answer to this objection is to remark that, even if some property of the law, such as its democratic origins, is what helps make it the case that we have a reason to do as the law demands, the fact that the law has such a property could not on its own, or fully, ground such a reason. In other words, although we might make the specific claim that

[The law's origins are democratic] partially grounds [ $S$ has a reason to $\phi]$, it would be misleading to claim simply that [The law's origins are democratic] grounds $[S$ has a reason to $\phi$ ] because it is not only the fact that the law has this property, but also the fact that the law demands that $S \phi$ 一that is, $S$ as a specific subject and $\phi$ as a specific act - which together fully ground the fact that $S$ has a reason to $\phi$. Alternatively, though we might, in the case we are imagining, truly claim that

[The law's origins are democratic] fully grounds [Subjects of the law have a reason to obey the law],

we would, in order to make a specific claim about what grounds $S$ 's reason to $\phi$, need to claim that 
[The law's origins are democratic] and [The law demands that $S \phi$ ] together ground $[S$ has a reason to $\phi]$.

We could not then, as this version of the objection urges, make the grounding claim only in terms of some fact or set of facts about the law's properties. And we should therefore not say that it is the law's origins, rather than the law itself, which give us a reason to do as it demands.

It should be said too that when considering which properties $\{P\}$ may help ground our reasons to do as the law demands, not just any properties will do. For, as I have argued, the property that the law codifies morality could not partly ground a reason for action. The properties in question must be, rather, distinctive properties of the law in order to be able to help ground a reason to obey the law, in the way that, for example, we might call some law's democratic origin, or its being part of a certain kind of fair system of social cooperation, or its being issued by a law-giving body whose authority was consented to, such distinctive properties. ${ }^{28}$ While we could make the grounding claim only in these terms, we could also usefully summarize this grounding claim as a claim about why we have reasons to obey the law because it is the law. In other words, we may call the reasons grounded in these ways legal reasons, and we may claim that learning we have such reasons tells us something important about the normativity of the law rather than merely about other familiar sources of normativity. If we learn that democratic lawmaking, or legal fair play, or consent to the law can help ground such reasons, we learn something not only about the normativity of democracy, fairness, or consent, but about the moral force of the law itself.

\subsection{External Objections}

We can turn next to a different kind of objection, which takes issue not with what is entailed by the view proposed here but with what it may seem to lack. In classic discussions of the idea, content independence is typically mentioned in the same breath as another property, which Hart calls "peremptoriness," Raz calls "preemptiveness," and Rawls, though he does not give it a name, seems to have had in mind in discussing what he calls "rules of practice." 29 The thought uniting these discussions (which I will consider in more detail shortly) is that

We can also see in this way how some putatively or apparently normative properties of the law might fail to be truly normative. If a democratic lawmaking process, and the laws it produces, are justified because those laws are more likely to accurately reflect underlying moral demands, this may ground a reason to believe that we ought to do as the law demands, but it could not itself ground a further reason to so act. 
content-independent reasons to obey the law often render certain other considerations opaque to those subject to them-normally, the underlying considerations that justify such reasons, or other reasons for or against the thing the reason is a reason to do-by excluding those considerations from a subject's practical deliberation. By contrast, I have suggested that we may understand the question about the law's force simply in terms of its distinctive normative properties, and that we may answer that question, or begin to, by thinking about the reasons grounded by those properties. This suggests a picture of the relationship between subjects and the law that is transparent with respect to the grounds and strength of the law's normative force. It may thus be objected that the view proposed here is incompatible with the law's opacity. ${ }^{30}$

As before, we can helpfully distinguish several more precise versions of this objection. The first takes as its inspiration Hart's and Raz's famous discussions of authoritative reasons, which they argue are both content independent and opaque.

Hart writes (endorsing a view he attributes to Hobbes) that

[a] commander characteristically intends his hearer to take the commander's will instead of his own as a guide to action and so to take it in place of any deliberation or reasoning of his own: the expression of a commander's will that an act be done is intended to preclude or cut off any independent deliberation by the hearer of the merits pro and con of doing the act. ${ }^{31}$

He calls authoritative reasons that succeed in cutting off deliberation in this way "peremptory."

Raz, discussing the same topic, writes:

One thesis I am arguing for claims that authoritative reasons are preemptive: the fact that an authority requires performance of an action is a reason for its performance which is not to be added to all other relevant reasons when assessing what to do, but should exclude and take the place of some of them. ${ }^{32}$

Following these thoughts, it might be objected that opacity and content inde-

The Morality of Freedom, chs. 2-3, and Practical Reason and Norms; and Rawls, "Two Concepts of Rules."

30 I thank an anonymous reviewer for encouraging me to address this point and for suggesting the term "opacity."

31 Hart, Essays on Bentham, 253.

32 Raz, The Morality of Freedom, 47 (emphasis removed from original). 
pendence are analytically tied, and that the view I have proposed in this paper cannot accommodate this. For I have suggested that, in asking whether we have reasons to obey the law, we should look to the various distinctive normative properties of the law as grounds of such reasons, whereas opacity seems to require that we-in our role as subjects of the law-refrain from precisely this kind of inquiry.

There are several answers to Hart's and Raz's challenge. It is important to note, first, that content independence and opacity are not analytically tied tout court, in the sense that neither is a property of or entails the other, nor are they necessarily mutually coextensive. ${ }^{33}$ That this is so is clear enough as a matter of reflection, I think, but can also easily be seen by considering the case of threats. Threats are archetypally content independent-one's reason to do as a threatener demands (if one has such reason) arises in virtue of the threat rather than in virtue of what it is demanded that one do-yet they are not also opaque. One thought, already mentioned, is that the grounds of opaque reasons are not transparent (or not meant to be transparent) to those to whom they apply. But of course, the transparency of the facts which ground a threat's normative forceviz., the badness of the threatened consequences together with the conditional assurance that they will be brought about-is crucial to the threat's functioning. Another thought, following Hart and Raz, is that opaque reasons replace or exclude from consideration other reasons bearing on the act in question. Yet threats do no such thing. Indeed, to weigh the reason given by the threat together with all of one's other reasons for and against doing the thing demanded seems precisely what is called for in such cases. Threats, then, are not plausibly sources of opaque reasons, though they are clearly content independent. So it cannot be that the two properties do not come apart.

It may be, however, that in the domain of interest, content independence and opacity always come together. This leads to a second point. For both Hart and Raz, opacity and content independence are discussed as part of their analyses of authoritative reasons. Moreover, while content independence is acknowledged to be a property of many reason types, the possession of the further property of opacity is what is said to be a distinctive characteristic of authoritative reasons. I shall consider in a moment whether anything I have said is incompatible with this conception of authoritative reasons. But before that, it is worth noting that

33 Neither Hart nor Raz appear to take opacity and content independence to be analytically linked in this sense. Hart discusses what he calls the "peremptory character" of authoritative reasons separately and before discussing their content independence. See Hart, Essays on Bentham, 254. Raz discusses content independence and "preemption" in different chapters entirely of The Morality of Freedom, and the two are nowhere discussed together in his major work on exclusionary reasons, Practical Reason and Norms. 
I have not endeavored in this paper to offer an account of the authority of law, only to ask whether it provides content-independent moral reasons to do as it demands. Whether opacity is a feature of what it is for a reason to be authoritative, as Hart and Raz suggest, is not a matter we should expect our more modest question to pertain to.

This narrow point conceals a broader one. If the arguments in the remainder of this paper are correct, then we may conclude that the law often provides content-independent moral reasons to do as it demands, and moreover that these reasons often amount to obligations. This conclusion alone undermines a central strand of philosophical anarchism. The fact that we may reach this conclusion without asking the further question of whether the law, in providing these reasons, does so authoritatively — as well as what this means, and what it addsis of theoretical interest in itself. We should take care to distinguish, in thinking about the normativity of the law, the question of whether it has reason-giving moral force from the question of whether it is authoritative. It is a virtue of the approach taken here that it allows us to see the space between these two questions. $^{34}$

The challenge that remains is that the view proposed in this paper is incompatible with the opacity of authoritative reasons to obey the law. If Hart or Raz is correct about the character of the authority of the law, and if we do indeed have authoritative reasons to obey the law, then this incompatibility would count as a strike against this paper's main claims. I believe, however, that the view of content independence proposed here is compatible with Hart's and Raz's notions of opacity. To see this, it will help to describe more precisely their views.

For Raz, an authoritative reason is really two reasons: a "first order" reason for action as well as an "exclusionary reason," which is a species of "second order" reason:

A second order reason is any reason to act for a reason or to refrain from acting for a reason. An exclusionary reason is a second order reason to refrain from acting for some reason. ${ }^{35}$

An authoritative reason to $\phi$ is thus, on this view, both a first-order reason to $\phi$

34 The topic of the law's authority is too large and difficult a topic to enter into in this already lengthy discussion. I take up the question of the law's authority in further work. See Flanigan, "Essays at the Limits of the Law."

35 Raz, "Reasons for Action, Decisions and Norms," 487. The nature of second-order reasons is a point of controversy. See Piller, "Kinds of Practical Reasons"; Whiting, "Against Second-Order Reasons"; and Scanlon, "Reason and Value." These are recent discussions, though as Raz notes in the postscript to Practical Reason and Norms, the history of this debate goes back at least four decades. 
as well as a second-order reason to refrain from acting for other reasons favoring or disfavoring $\phi$-ing. This structure is familiar, Raz claims, from promises, which also generate exclusionary reasons. By way of illustration (to borrow one of Raz's examples), if one has promised to consider only one's child's interests in decisions about the child's schooling, then one has an exclusionary reason not to make such decisions for (among other things) self-interested reasons, such as that it would require a career sacrifice, mean fewer vacations, require substantial time driving to and from the campus, and so on. These reasons are not to be considered in deliberation about how to best educate the child.

Though he does not say so in exactly these terms, what Hart has in mind is something similar. Here he is again:

The expression of a commander's will that an act be done is intended to preclude or cut off any independent deliberation by the hearer of the merits pro and con of doing the act. ${ }^{36}$

Insofar as Hart is making a claim about the character of authoritative reasons (rather than the mental states of those issuing commands), we should read him as claiming that, in addition to being a reason to $\phi$, an authoritative reason also has the effect of prohibiting further deliberation about whether to $\phi$. A strong reading of this prohibition would preclude any contemplation of the merits of $\phi$-ing; a weak reading would only preclude such considerations from figuring in deliberation about whether to $\phi \cdot{ }^{37}$ On either reading, Hart is suggesting, like $\mathrm{Raz}$, that authoritative reasons also regulate a subject's proper consideration of the various other reasons that may favor or disfavor $\phi$-ing, and so we may treat both as holding the view that authoritative reasons entail exclusionary reasons.

Hart's and Raz's claims are thus about the scope of reasons for which it is appropriate for subjects to $\phi$ when the law authoritatively demands that they $\phi$, as a matter of practical deliberation. It is not about the considerations that in fact count in favor of $\phi$-ing, nor is it about the further facts that ground the law's authority in that case. It might therefore be the case both that (as I have claimed)

1. [The law has some properties $\{P\}]$ and [The law demands that $S \phi]$ together ground $[S$ has a reason to $\phi]$,

and that (as Hart and Raz claim)

2. The reason for which $S$ should $\phi$ is [The law demands that $S \phi$ ] together with [The law is authoritative]. 
There is no incompatibility here: 1 is about the grounds of subjects' reasons to obey the law, and 2 is about the reasons for which subjects should act when they consider whether to do as the law demands. If it is also true (though it might not be) that the properties of the law $\{P\}$ are those that make the law authoritative, then 1 will help explain 2. (Subjects must also deliberate regarding whether a reason is authoritative, in order to know whether 2 applies to them; 1 may in that case help them to do so.) If not, then the reasons grounded by those properties will be superfluous to a subject's deliberation whether to $\phi$. In either case, if these theories about authority are correct, there is a deliberative opacity between 1 and 2 but no conflict. Again, it is a virtue of the approach taken here that it allows us to clearly see this relationship.

As I said, there is another version of this objection. This objection is deeper, because according to it, content independence and opacity emerge as structural or logical consequences of the law as a rule-governed practice, such that moral reasons to obey the law because it is the law must be opaque. ${ }^{38} \mathrm{~A}$ version of this objection is suggested by Rawls, who argues that "the rules of practices are logically prior to particular cases," which is to say that

given any rule which specifies a form of action (a move), a particular action which would be taken as falling under this rule given that there is the practice would not be described as that sort of action unless there was the practice. In the case of actions specified by practices it is logically impossible to perform them outside the stage-setting provided by those practices, for unless there is the practice, and unless the requisite proprieties are fulfilled, whatever one does, whatever movements one makes, will fail to count as a form of action which the practice specifies. What one does will be described in some other way. ${ }^{39}$

As an example, Rawls offers the rules of baseball. In baseball, to record three strikes at bat just is to strike out, and the act of "recording a strike," as well as the states of being "at bat," "out," and so on are defined by the rules of baseball. Thus, the question

Shall I stay at bat after my third strike?

can only be answered, and an answer can only be justified, by reference to the rules of baseball. After a third strike, one has struck out; and once one has struck

Note that this objection does not claim opacity is a property of content independence generally, just that the two are coextensive in the domain of reasons to obey the law, and other structurally similar domains, in virtue of the structure of those domains.

Rawls, “Two Concepts of Rules,” 25 (emphasis in original). 
out, one is no longer to be at bat. This is true even though in another frame of mind, we might wonder whether the rules of baseball are the best rules, should be amended, and so on. As a player, Rawls argues, such considerations simply do not bear on the question of what to do, and so are excluded from a player's deliberation about how to act.

Since this question is about one of the many rules of baseball, the same might be thought true of the general question

Shall I obey the rules of baseball?

Likewise, the answer to this question might be thought to be given only by the fact of whether one is playing baseball or not. If one is playing, the rules simply apply to one, and further considerations are excluded. So while one might ask in the first instance whether to play baseball or not, once one has decided to play, there is no further question of whether to play as the rules demand. To play just is to have the rules apply. The general question is thus necessarily answered in the affirmative.

This way of conceiving rules of practice renders the reasons given by them content independent. An individual player is to take as her reason for (say) returning to the dugout the fact that she is out, which is made true by the three strikes she has had at bat. Both are made true by the rules of baseball, which might have defined being "out" differently or which might have required something else of a player who strikes out. Her reason to return to the dugout is thus grounded by the fact that the rules apply to her together with the fact of what the rules require, rather than by the independent merits of returning to the dugout or not. It is, in this way, content independent.

Importantly, this form of content independence is also opaque with respect to the underlying justification of the rules. This is because the normative properties of the rules which justify them-e.g., that they are most conducive to fun, competition, fairness, and so on-do not also ground the fact that the player is out or the fact that the rules apply to her. ${ }^{40}$ Those properties do not therefore ground the player's reason to return to the dugout. Since the normative properties of the rules do not ground the player's reason to obey them, the reason is therefore opaque with respect to those properties, and they are excluded as reasons bearing on what she is to do.

This is slightly too quick. The same considerations that justify the rules may, depending on our view, also play some part in grounding the fact that they apply to players. Even if they do, however, variations in those considerations-e.g., just how conducive to fun this rule is-would affect a player's reason to obey only if they altered the fact of whether the rules applied or not, which presumably most such considerations would not. The player's reason to obey the rule, then, would remain opaque with respect to those considerations. 
It is easy to see, by analogy, how the same might be thought true of the law and our reasons to do as it demands. For just as some acts and states are defined by the practice of baseball, so too we might think that some acts and states are defined by the law. ${ }^{41}$ Thus, perhaps the question

Shall I pay $x$ dollars to the tax collector?

can only be answered by reference to the law of the land, since the tax regime, the office of the tax collector, and even the dollar and the very notion of tax are defined by the law. Again, it might be thought that the tax law simply applies to one, such that there is no intelligible question of whether to obey. (Or at least that this is true insofar as the tax law applies to one.) And while there may be good reasons to adopt this tax code or that one, such questions apply at the level of legislation and regulation, not to an individual subject wondering whether to write a check for $x$ dollars to the revenue service.

Again, likewise, it might be thought that this question about taxes is just one instance of the more general question

Shall I obey the law?

and that the interrogative form of this general question disguises the important truth that the law simply applies to those subject to it. We are all playing, and the rules apply to us all.

If this were true, then content independence would similarly be a structural property of the way the law creates demands on its subjects, and the reasons for those subjects to obey would be opaque with respect to the considerations that justify the law itself.

However, whatever conclusions we should draw from Rawls's argument, it should be clear that they cannot be these. We can intelligibly ask whether or not to obey the law, or this law or that law, even when the acts we are considering whether or not to do are defined by the law; and the mere fact of the law's application to us cannot settle that question. Indeed, we can see on reflection that precisely the same is true of a player wondering whether to obey the rules of a game.

This is, first, because on Rawls's analysis, a question of the form

Shall I stay at bat after my third strike?

and in the relevantly similar sense, so too the question

41 Rawls makes this point by offering the example of rules of punishment. I think the example of taxes is an easier one, and so I shall proceed with it, but nothing is meant to hang on this choice. See Rawls, “Two Concepts of Rules," 10-18. 
Shall I pay $x$ dollars to the tax collector?

is a question not about what to do but rather a question about what the rules are. They are thus not particular instances of more general questions about whether to obey the rules. To the contrary, that general question can still be asked in both cases. ${ }^{42}$ Perhaps the player has reasons to break the rules by staying at bat after a third strike-reasons from within the game, such as that it would beneficially delay the game, or reasons from without, such as that doing so would serve as some political protest. ${ }^{43}$ Then the player may sensibly ask whether or not to obey that rule, as a way of asking whether to continue within the practice. Likewise, those subject to the law may sensibly ask whether or not to do as it demands. We can ask this question from within the practice, and considerations from both within and outside of the practice can bear on the answer. Since we are concerned here with the question of whether to obey the law, not the question of what the law demands when it applies to us, it is important that the former question is seen not to be opaque with regard to reasons that come from outside the practice. It is, rather, transparent in precisely the way I have been suggesting so far.

Second, Rawls himself suggests that questions about acts that are practice defined may be redescribed in other, nonpractice-defined terms, or may inevitably entail giving answers to such questions. ${ }^{44}$ Thus to answer the question

Shall I stay at bat after my third strike?

might also be described as, or entail an answer to, the question

Shall I continue standing here, on this spot, now?

The latter question makes no necessary reference to practice-defined states or acts, and so may be answered by reference to all of the reasons for and against continuing to stand in that spot. (Perhaps you promised you would do so; perhaps you are being threatened not to move; etc.) Importantly, the answer to this

42 Rawls recognizes this point when he writes that if one's appeal to the rules is not accepted, "it's a sign that a different question is being raised as to whether one is justified in accepting the practice, or in tolerating it." See Rawls, "Two Concepts of Rules," 27.

43 Whether strategic rule breaking is an act within a practice or an abrogation of it is a vexed question that I cannot enter into here. On this question with respect to Rawls and baseball, see Palmiter, "Cheating, Gamesmanship, and the Concept of a Practice." There is also a lively debate regarding this question with respect to contracts and promises. See, e.g., Shiffrin, "The Divergence of Contract and Promise."

44 Rawls again: a practice-dependent act "would not be described as that sort of action unless there was the practice.... What one does will be described in some other way" ("Two Concepts of Rules," 25, emphasis in original). 
wider question may supersede the answer to the first, since it includes in it the value of abiding by the rules of the practice versus the disvalue of breaking them.

The point is easier to see when we consider certain questions of law. For Justice Lemuel Shaw, to answer the question

Shall I order Thomas Sims returned to slavery in accordance with the Fugitive Slave Act?

was also to answer the question

Shall I bring it about that Thomas Sims is re-enslaved?

The first question might have been decidable only by the standards of the law, but to answer that question was at the same time to answer the second question, which clearly involves wider moral considerations, including those concerning the value of the law itself. (This is true, I think, even if the state of enslavement is taken to be defined by a legal practice.) To argue that Shaw's question was fully settled by the law, or that the law simply applied to Shaw's judicial act, is to ignore the clear conflict between the demands of the statute and the requirements of morality. ${ }^{45}$

We can put the point generally. Systems of rules generate, for those subject to them, content-independent reasons: insofar as one is aiming to act within a practice, one's reason to $\phi$ arises in virtue of the rules of the practice, rather than in virtue of facts about $\phi$-ing as such. From within the practice, one's reason to $\phi$ may be opaque. But one can also ask whether the act required by the practice can be redescribed in other terms, or whether to decide to do that act is also to decide to do some further act. Wider considerations may bear on this further question, and the answer to it may impinge on the answer to the first. The opacity of rule-given reasons, then, may in this way be made transparent.

If I am right about these ways to answer Rawls's challenge, then this version of the objection fails as well. Even for practice-defined acts demanded by the law, we can ask whether we ought to do them. This question is not opaque: it calls for us to think about the various normative properties of the law that might give us reason to obey or disobey. It also, in the manner I have been describing, remains content independent: if we have reason to obey, it will be in virtue of those distinctive properties of the law, rather than in virtue of properties of the thing the law demands we do.

45 Shaw infamously ordered Sims returned to slavery. For details of the case, see Brown, "Thomas Sims's Case after 150 Years." 


\section{ANARCHISM}

Even if it may be claimed, as I have argued it may, that there could be genuinely normative, content-independent moral reasons for action given by the law, it remains to be shown that such reasons do in fact exist (or, as I shall more modestly claim, that it is plausible that such reasons exist). We can turn finally, then, to the question of whether, and in what sense, we might truly claim about the law that it provides such reasons.

Let us begin with the easier issue of in what sense we might truly make such claims. As I noted at the beginning of this essay, it is telling that the "traditional question" in the study of legal obligation, and indeed the name of the field itself, concerns not reasons to obey the law but our obligation to do as it demands. We may restate this traditional question of whether we are obligated to obey the law, because it is the law, as the "obligation question":

Does the law provide genuinely normative, content-independent, and normally decisive moral reasons to do as it demands ${ }^{46}$

In order to answer yes to this question, we would need to identify some property or properties of the law which, together with the law's demanding that we act, fully ground our having normally decisive moral reasons to so act.

I do not doubt that historically, some have thought it plausible to provide an affirmative answer to the obligation question and to identify such properties. We might, for instance, agree with the First Vatican Council that

1. the pope is the earthly representative of God and is preserved from the possibility of error,

2. the law as handed down by the pope (the "pope's law") is normatively binding, in the sense that we each have decisive reason to do as it demands,

and that therefore

3. the pope's law provides each of us with genuinely normative, content-independent, and decisive moral reason to do as it demands. ${ }^{47}$

Alternatively, as in an earlier example, we might hold a similar view about the obligation of subjects to obey the laws handed down to them by monarchs, in

As explained in section 1, I use "normally decisive reason" as a moderately ecumenical analysis of the concept of obligation.

47 Here, as before, it is helpful if we understand the pope's law as something more than a mere codification of God's law. 
view of the natural right of kings and queens. Such a right might, like the pope's, or as on Filmer's view, be grounded in divine right or revelation, or else, as on the common reading of Hobbes, be grounded in the necessary covenant of each to every other in order to gain protection from the war of all against all.

Such defenses of the affirmative answer to the obligation question do not, however, strike me as plausible, nor do I suppose they strike many as plausible today. And yet, despite this, writers persist in treating the obligation question as the one that demands an answer. ${ }^{48}$ This insistence, unsurprisingly, has led many to answer no, and instead to endorse some version of philosophical anarchism. For if we must endorse either the view that the law always gives us genuinely normative, content-independent, and normally decisive moral reasons to do as it demands, or the view that it gives us no reasons at all, the anarchist's choice is clearly the best one. Faced with such a dilemma, it would be difficult to adopt any other position.

But this dilemma, I think it is clear, is a false one. We should not normally expect the law to in all cases give us decisive reason to do as it demands. ${ }^{49}$ Rather, I believe we should expect the law in many cases to add to the balance of reasons in favor of doing as it demands, by providing some reason for action. The strength of the reasons so provided by the law may vary according to which property or properties give it normative force, but the reasons should be perceptible nonetheless when we look for them. Often, such reasons will do the more important job not merely of providing some reason to act but of contributing, alongside other reasons, to making it the case that we ought to do as the law demands, in the decisive reason-implying sense-and thus in part, we can add, to contributing to making it the case that we ought to do the thing the law demands because the law demands it. And occasionally, or so I shall argue, legal reasons may ground our obligations to do as the law demands not merely in part but rather fully make it the case that we ought to do as the law demands. In this way, then, we can see the law as giving us genuinely normative, content-independent moral reasons to do as it demands, in a way that does not amount or tend to any version of philosophical anarchism.

We can now turn to the more difficult question,

Which property or properties of the law, together with its demanding that we act, may plausibly give us a reason to so act?

48 See inter alia Dagger and Lefkowitz, "Political Obligation"; Green, "Legal Obligation and Authority."

49 I think we should make this claim even if we believe, as some do, that the law claims for itself the authority to create obligations, in the decisive reason-implying sense. 
It is worth emphasizing again that I shall pursue only the modest goal of attempting to show that certain properties of the law may plausibly help give us genuinely normative, content-independent moral reasons for action, rather than attempting to mount a conclusive or even very strong argument that they do so. I shall do this by briefly sketching the ways in which theories of political and legal obligation may be easily and plausibly recast as theories of political and legal reasons. And although this weakens these theories, it also makes them more plausibly true; and moreover, when viewed in this way, I think we may more clearly see how these theories may together give us something resembling a blanket obligation to obey the law. ${ }^{50}$

I should first point out that many of the leading nonvoluntarist theories of political and legal obligation may be recast as more modest theories of sources of political and legal reasons. Fair-play theories provide a clear example. When Nozick objects, for instance, that we cannot come under an obligation to others simply because they have conferred some benefit upon us, we may answer that the conferral of certain benefits may nonetheless generate some reason for us to participate appropriately in the system of benefits. ${ }^{51}$ Such an answer is plausible even in his famous public address system case: when it is your turn, you are, let us agree, not obligated to perform, in the sense that you do not have a decisive reason to do so, but if you have enjoyed the fruits of the cooperative enterprise, then you may plausibly have some reason of fairness to do your part in the future. In the analog case of the state, this may result in reasons of fairness to obey the law. (I do not argue that this is clearly true, only that it is very plausibly trueand much more plausibly true than its original obligatory counterpart.)

Or, to take a similar example, when Klosko claims that

1. if some state is a cooperative enterprise, and

2. if this state, through its laws, provides its citizens with presumptively beneficial, fairly distributed goods,

he might conclude either that

3. the state's citizens have an obligation of fairness to obey its laws, or, instead, more modestly that

4. the state's citizens have reasons of fairness to do as its laws demand.

Klosko's conclusion is in fact 3 but it need not be: 4 is a weaker conclusion and is thus easier to establish and open to fewer objections. It is also, I think, much

50 See Klosko, "Multiple Principles of Political Obligation," who explores a version of this view.

51 Nozick, Anarchy, State, and Utopia, 90-95. 
more immediately plausibly true. The reasons given by 4 may or may not amount to an obligation to do as the law demands, but would rather provide us with some reasons, by counting in favor of our doing so.

Note here one important fact, which is that for theories like this to successfully give us genuinely normative content-independent legal (and moral) reasons for action, it must be some part of the law that provides us with the goods whose receipt grounds our reasons to obey the law's demands. That is to say, if we have reasons in virtue of some principle of fairness to do our part in some collective enterprise, those reasons are only legal reasons of the kind we have been here discussing if the product of the collective enterprise is in some way secured by the law. Otherwise, our reasons to do our part will be just that, and any specifically legal demand that we do so will merely restate those reasons rather than giving us new, additional ones.

Other nonvoluntarist theories of political and legal obligation may be similarly recast in this way, including theories built around principles of gratitude, samaritanism, and natural duty. That is because all such theories identify some moral principle that, they argue, is operative in virtue of the existence or some other feature of the law. Any such theory, as in the case of fair-play theories, may more easily establish that the moral principles they identify provide some reason to obey the law than that they provide normally decisive reasons to do so.

Recasting these theories in this way has benefits beyond making their conclusions easier to establish. Understood as independent sources of reasons to obey the law, these theories may be very naturally combined to generate stronger reasons to obey the law than any one of them provides on its own. It may also be the case that some principles provide reasons to obey the law in only some rather than all domains, or reasons whose strength varies across different domains of the law. Combining such principles may allow us to claim that there are widespread reasons to obey the law, because it is the law, in ways that would be impossible drawing on any one principle alone. Acknowledging this possibility, moreover, may help our theories better match our sense that it is in some cases much more important to obey the law than in other cases. The question facing these recast theories is thus not, "Is the principle relied upon by this theory sufficient to generate wide-ranging obligations to do as the law demands?" but, much more modestly, "Does the principle relied upon by this theory generate reasons to do as the law demands?"

A similar point may be made about theories attempting to ground an obligation to obey the law in the fact of some laws' democratic provenance. Such theories claim that 
$[L$ was generated by a democratic process $]$ and $[L$ demands that $S \phi]$ together ground $[S$ has an obligation to $\phi]$.

Naturally, however, we might instead make the more modest claim that

$[L$ was generated by a democratic process $]$ and $[L$ demands that $S \phi]$ together ground $[S$ has a reason to $\phi]$.

In these claims, of course, [ $L$ was generated by a democratic process] stands in for a more complex statement of the feature or features had by democratic laws in virtue of which those subject to them may be obligated or have reason to do as they demand. When Christiano argues, for instance, that (roughly) democratically created laws treat each citizen equally with respect to certain questions about what we together should do, regarding which no one has greater claim or standing to give an answer than any other, or when Kolodny writes that "the concern for democracy is rooted in a concern not to have anyone else above-or, for that matter, below-one," each is arguing that it is this more specific feature of democratically created laws which in part grounds our obligation to obey those laws. ${ }^{52}$

This is not, I should say again, the place to engage in a discussion of whether Christiano's or Kolodny's claims, or those of other democratic theorists, about democratic political obligation succeed, nor do I here mean to endorse either's claim to that effect or my suggested weaker version of those claims. Rather, I mean only to claim that these arguments provide plausible accounts of one source of genuinely normative, content-independent moral reasons to do as the law demands; and that, as with the nonvoluntarist accounts I made similar claims about earlier, such accounts of the source of legal reasons may be combined with others, and may vary in presence and strength across different domains of the law.

Some consent theories may also be recast in this way. According to consent theories, $S$ is obligated to obey $L$ just when and because some combination of 1-4 holds:

1. Ordinary consent: $S$ has consent to do as $L$ demands.

2. Tacit consent: $S$ has tacitly consented to do as $L$ demands.

3. Hypothetical consent: $S$ would so consent if $S$ knew all the facts, deliberated rationally, and so on.

4. Normative consent: $S$ should so consent.

Of course, if $S$ has consented to obey the law, it may often be accurate to claim 
that $S$ is obligated to do as it demands, because $S$ 's consent grounds a normally decisive reason to do so. But it is worth emphasizing with respect to conditional and normative consent theories that these theories may be much more plausible as theories of the sources of reasons to do as the law demands rather than the sources of obligations to do so. It is much more plausible, for example, to argue that $[S$ would consent to obey the law] gives $S$ a reason to obey the law than that it gives her an obligation to do so. ${ }^{53}$ (Of course, such a reason may alongside others amount to a decisive reason. In this way, conditional or normative consent to a law may partially ground an obligation to obey it.)

There is one other plausible source of genuinely normative, content-independent moral reasons to obey the law that I wish to take a bit more time over here, because I believe it may be of particular importance. This source is the law's often unique ability to solve coordination problems.

It will help to consider the case of traffic laws. Those of us who drive each have some reasons not given by the law to drive in certain ways: these can be helpfully summed up by saying that we have all the summary reason to drive safely. One of the reasons summarized by this reason is the reason we all have to drive on one side of the road; another is to drive at a safe speed. But these reasons are in an important sense incomplete. If we are driving, say, on many highways in the United States, we have reasons to drive on the right side of the road and to drive in the vicinity of $55 \mathrm{mph}$. When we are in other places and on other roads, these reasons change. But wherever we are, these reasons are grounded by facts about the law.

This last claim might be doubted. The speed at which we have reason to drive on some road, for instance, is determined partly by the road itself, by the capabilities of our cars, and by how fast and how many others are traveling. It may seem that the legal speed limit is superfluous, or that it merely formalizes these other reasons. But this argument neglects the further reason we all have to drive in the vicinity of some single, particular speed. Which speed this is may be limited by the road, our cars, and how many of us there are, but this speed is not fully determined by these facts. The law accomplishes this latter task.

Similarly, it may be rightly pointed out that the law is not a necessary ground of our reasons to drive on this or that side of the road. If there were no law concerning which side of the road to drive on, people might just work out for themselves some convention. If they did, these people would have a reason to drive on whichever side of the road that convention dictated.

Equally, if the law in some place demanded that we all drive on the left,

53 See Enoch, "Hypothetical Consent and the Value(s) of Autonomy"; Stark, "Hypothetical Consent and Justification." 
whereas in fact everyone followed the practice of driving on the right, each driver would have most reason to drive on the right—and it is plausible to think that each driver would have no reason to drive on the left.

But this is not an objection to the view I am defending. I do not claim that the law is a necessary ground for our reasons to drive on one side or another, or to drive at a certain speed; I am claiming only that it is in fact the ground of many of our actual such reasons. It is not enough to say that we each have a reason to drive on the side of the road on which most other drivers drive. We together must at some point take some actions or decisions which determine the particular side that is. This could take the form of legislation, or it could be established through more complex patterns of convention. In the actual case of the United States, I submit that it is the law that secures the relevant convention; it is the fact that the law demands that we drive on the right which partially grounds our reason to drive on the right. In other words, we cannot state the facts which ground

[we each have reason to drive on the right side of the road in the United States]

or

[we each have reason to drive near $55 \mathrm{mph}$ on certain highways in the United States]

without making reference to the fact that the law demands that we do so. We may thus, as I argued earlier, call our reasons to drive in these ways content-independent legal reasons. ${ }^{54}$

Reasons given by coordination problems solved by the law such as these may be, I believe, quite weighty reasons. Very seldom will I have sufficient reason to drive on the side of the road other than the side demanded by the law. I think it is therefore fair to say that we are obligated to drive on the side of the road demanded by the law, and we are so obligated because it is what the law demands.

We can next observe that traffic laws are not a special case, but rather one of very many sets of laws whose purpose is to solve coordination problems. I shall not defend this claim at length here, except to mention that many of the core functions of political organization are to help us live our lives together, and include the establishment of property regimes, monetary systems, rules of ex-

54 It might be further objected that the law here merely happens to provide the relevant convention - that the reasons to drive on the right side of the road, or around $55 \mathrm{mph}$, are not grounded by the law in virtue of its being the law, or in other words by the law's authority as such, but rather by the law in virtue of its establishing the relevant convention. But the fact that the law establishes certain conventions may quite plausibly be part of what grounds its authority in the relevant domains. 
change, and indeed traffic laws, all of which are at least partly conventional; and so the reasons we may have with respect to these domains of law will be at least partly grounded in the fact of the law's demands. ${ }^{55}$ If I am right that conventionally determined reasons of this kind are genuinely normative, content-independent moral reasons for action, then it seems that they are quite widespread and quite forceful. On their own they might license my claim that we do plausibly often have genuinely normative, content-independent moral reasons to obey the law; and combined with the other plausible sources of such reasons I have already mentioned, we may well be obligated to obey the law, because it is the law, much more often than we might otherwise have thought.

\section{CONCLUSION}

It may now help to sum up some of my main claims. I have argued that when we consider the question,

Do we have reasons to do as the law demands, because it is what the law demands?

we should understand the "because" in the question as the because of grounding. On the view I have defended, if we have such reasons, it is because there is some fact about the law that at least partially grounds the fact that we have such a reason. This, on my view, is what we should mean when we claim that the law may be a source of content-independent reasons to do as it demands.

I argued next that, once we see that this is what it is to be a content-independent reason to obey the law, we can see that we very plausibly have many such reasons. This is because many of the leading theories of political and legal obligation may be recast as theories about content-independent reasons to do as the law demands. When recast in this way, these theories' main claims are easier to establish; and although they are thereby individually weaker, they may gain

55 David Lewis mentions this in Convention, and there is also a sizeable jurisprudential literature concerning coordination, convention, and the law. See inter alia Gans, "The Normativity of Law and Its Co-Ordinative Function"; Ullmann-Margalit, "Is Law a Co-Ordinative Authority?"; Postema, "Coordination and Convention at the Foundations of Law”; Green, "Law, Co-Ordination and the Common Good"; Green, The Authority of the State, ch. 4; and Raz, The Morality of Freedom, 30. Marmor admits that coordination problems can ground obligations but also claims that this cannot explain the full extent of the law's normative power ("The Dilemma of Authority"). Like Ripstein, I am inclined to disagree. On Ripstein's construction of Kant's political philosophy, nearly all of our political duties are "determined" in this way by the state and the state's laws. For some considerations along these lines, see Ripstein, Force and Freedom, as well as Pallikkathayil, "Deriving Morality from Politics"; Julius, "Independent People" and "Public Transit." 
the advantage of being true, and they may also be combined with each other to provide stronger summary reasons to obey the law. Understanding our reasons to obey the law in this way, I claimed, may also help explain our intuition that such reasons may vary in strength across various circumstances and the various domains of the law. If these theories may be recast and combined in this way, I also argued, and if the law is a source of content-independent reasons for action in the many cases in which it helps solve coordination problems, then such legal reasons may very often be sufficiently strong to make it the case that we ought to obey the law. In other words, we may often have more than content-independent moral reasons to obey the law-we may have obligations to do so.

I have also argued that we need not be philosophical anarchists just because we believe that no one theory of political and legal obligation has successfully established such an obligation. We should, I suggested, be engaged in the more modest enterprise of looking for reasons to obey the law, and then investigating their strength and the domains over which they range. In this way, I believe, we are likely to find a picture of our reasons for obeying the law that more accurately reflects our considered views, and, importantly, a picture that does not tend toward anarchism. ${ }^{56}$

Harvard University eflanigan@g.harvard.edu

\section{REFERENCES}

Berker, Selim. "The Unity of Grounding." Mind 127, no. 507 (July 2018): 729-77. Brown, Thomas J. "Thomas Sims's Case after 150 Years: A Motion to Reconsider." Massachusetts Legal History: A Journal of the Supreme Judicial Court Historical Society 7 (2001): 95-118.

Christiano, Thomas. "The Authority of Democracy." Journal of Political Philosophy 12, no. 3 (September 2004): 266-90.

Cohen, G.A. Rescuing Justice and Equality. Cambridge, MA: Harvard University Press, 2009.

Dagger, Richard, and David Lefkowitz. "Political Obligation." The Stanford Ency-

56 I owe special thanks to Selim Berker and Derek Parfit for their extensive and extremely helpful comments on an early draft of this paper. Small tribute though it is, I dedicate this paper to Derek Parfit in memoriam. I am also particularly indebted to James Brandt, who read and commented on several drafts. For further helpful comments and discussion, I thank Adriana Alfaro Altamirano, Arthur Applbaum, Eric Beerbohm, Noam Gur, Chris Havasy, and two anonymous reviewers for this journal. 
clopedia ofPhilosophy (Fall 2014). https://plato.stanford.edu/entries/political -obligation.

Edmundson, William A. "State of the Art: The Duty to Obey the Law." Legal Theory 10, no. 4 (December 2004): 215-59.

Enoch, David. "Hypothetical Consent and the Value(s) of Autonomy." Ethics 128, no. 1 (October 2017): 6-36.

- "Reason-Giving and the Law." In Oxford Studies in Philosophy of Law, vol. 1, edited by Leslie Green and Brian Leiter, 1-38. Oxford: Oxford University Press, 2011.

Estlund, David. Democratic Authority. Princeton, NJ: Princeton University Press, 2008.

Fine, Kit. "Guide to Ground." In Metaphysical Grounding, edited by Fabrice Correia and Benjamin Schnieder, 37-80. Cambridge: Cambridge University Press, 2012.

Flanigan, Edmund. "Essays at the Limits of the Law." PhD diss., Harvard University, forthcoming.

Gans, Chaim. "The Normativity of Law and Its Co-Ordinative Function." Israel Law Review 16, no. 3 (1981): 333-49.

Green, Leslie. The Authority of the State. Oxford: Clarendon Press, 1988.

. "Law, Co-Ordination and the Common Good." Oxford Journal of Legal Studies 3, no. 3 (Winter 1983): 299-324.

. "Legal Obligation and Authority." The Stanford Encyclopedia of Philosophy (Winter 2012). https://plato.stanford.edu/entries/legal-obligation.

Gur, Noam. "Are Legal Rules Content-Independent Reasons?” Problema 5 (2011): 175-210.

Hart, H.L.A. Essays on Bentham: Jurisprudence and Political Philosophy. Oxford: Oxford University Press, 1982.

_. "Legal and Moral Obligation." In Essays in Moral Philosophy, edited by A. I. Melden, 82-107. Seattle: University of Washington Press, 1958.

Jay-Z and Kanye West. "No Church in the Wild." Track 1 on Watch the Throne. Roc-A-Fella Records, Roc Nation, and Def Jam Recordings, 2011.

Julius, A.J. "Independent People." In Freedom and Force: Essays on Kant's Legal Philosophy, edited by Sari Kisilevsky and Martin Stone, 91-110. London: Hart Publishing, 2017.

- "Public Transit." In Reasons and Intentions in Law and Practical Agency, edited by George Pavlakos and Veronica Rodriguez-Blanco, 159-75. Cambridge: Cambridge University Press, 2015.

Klosko, George. "Are Political Obligations Content Independent?" Political Theory 39 , no. 4 (2011): 498-523. 

(2004): 801-24.

Kolodny, Niko. "Rule over None II: Social Equality and the Justification of Democracy." Philosophy and Public Affairs 42, no. 4 (Fall 2014): 287-336.

Lewis, David. Convention. Cambridge, MA: Harvard University Press, 1969.

Locke, John. Two Treatises of Government. Edited by Peter Laslett. Cambridge: Cambridge University Press, 1988.

Markwick, Paul. "Independent of Content." Legal Theory 9, no. 1 (March 2003): 43-61.

_- "Law and Content-Independent Reasons." Oxford Journal of Legal Studies 20, no. 4 (Winter 2000): 579-96.

Marmor, Andrei. “The Dilemma of Authority." Jurisprudence 2, no. 1 (2011): 12141.

Nozick, Robert. Anarchy, State, and Utopia. New York: Basic Books, 1974.

Pallikkathayil, Japa. "Deriving Morality from Politics: Rethinking the Formula of Humanity." Ethics 121, no. 1 (October 2010): 116-47.

Palmiter, Brian. "Cheating, Gamesmanship, and the Concept of a Practice." Unpublished manuscript.

Parfit, Derek. On What Matters. 3 vols. Oxford: Oxford University Press, 20112017.

Piller, Christian. "Kinds of Practical Reasons: Attitude-Related Reasons and Exclusionary Reasons." In Analyses, edited by S. Miguens, J.A. Pinto, and C.E. Mauro, 98-105. Porto: Porto University, 2006.

Postema, Gerald J. "Coordination and Convention at the Foundations of Law." The Journal of Legal Studies 11, no. 1 (January 1982): 165-203.

Rawls, John. A Theory of Justice. Rev. ed. Cambridge, MA: Harvard University Press, 1999.

—. "Two Concepts of Rules." The Philosophical Review 64, no. 1 (January 1955): 3-32.

Raz, Joseph. The Morality of Freedom. Oxford: Clarendon Press, 1986.

- Practical Reason and Norms. 2nd ed. Oxford: Oxford University Press, 1999.

__ . "Reasons for Action, Decisions and Norms." Mind 84, no. 336 (October 1975): 481-99.

Ripstein, Arthur. Force and Freedom. Cambridge, MA: Harvard University Press, 2009.

Rosen, Gideon. "Metaphysical Dependence: Grounding and Reduction.” In Modality, edited by Aviv Hoffmann and Bob Hale, 109-36. Oxford: Oxford University Press, 2010. 
Ross, W.D. The Right and the Good. Edited by Philip Stratton-Lake. Oxford: Clarendon Press, 2002.

Scanlon, T.M. Being Realistic about Reasons. Oxford: Oxford University Press, 2014.

- "Reasons: A Puzzling Duality?" In Reason and Value: Themes from the Moral Philosophy of Joseph Raz, edited by R.J. Wallace, Philip Pettit, Samuel Scheffler, and Michael Smith, 231-46. Oxford: Clarendon Press, 2004.

Sciaraffa, Stefan. “On Content-Independent Reasons: It's Not in the Name." Law and Philosophy 28, no. 3 (May 2009): 233-60.

Shiffrin, Seana Valentine. "The Divergence of Contract and Promise." Harvard Law Review 120 (2007): 708-53.

Smith, Matthew Noah. "Political Obligation and the Self." Philosophy and Phenomenological Research 86, no. 2 (March 2013): 347-75.

Stark, Cynthia A. "Hypothetical Consent and Justification." The Journal of Philosophy 97, no. 6 (June 2000): 313-34.

Ullmann-Margalit, Edna. "Is Law a Co-Ordinative Authority?" Israel Law Review 16 , no. 3 (1981): $350-55$.

Whiting, Daniel. "Against Second-Order Reasons." Noûs 51, no. 2 (June 2017): 398-420.

Wolff, Robert Paul. In Defense of Anarchism. New York: Harper and Row, 1970. 